\title{
Body composition, dietary carbohydrates and fatty acids determine post-fertilisation development of bovine oocytes in vitro
}

\author{
S J Adamiak ${ }^{1,2}$, K Powell ${ }^{1}$, J A Rooke ${ }^{1}$, R Webb $^{2}$ and K D Sinclair ${ }^{1,2}$ \\ ${ }^{1}$ Scottish Agricultural College, Craibstone Estate, Bucksburn, Aberdeen AB21 9YA, UK and ${ }^{2}$ University of \\ Nottingham, Sutton Bonington Campus, Loughborough LE12 5RD, UK
}

Correspondence should be addressed to K Sinclair; Email: Kevin.Sinclair@nottingham.ac.uk

K Powell is now at VLB Group, Biosciences 2, Cardiff University, Cardiff, S. Glamorgan CF10 3US, UK

\begin{abstract}
This study assessed the interactive effects of carbohydrate type (fibre vs starch) and fatty acid (FA) supplementation ( $0 \%$ vs $6 \%$ calcium soaps of palm oil FA) on the post-fertilisation development of oocytes recovered from low and moderate body condition score (BCS) heifers. A secondary objective was to compare the FA composition of plasma to that of granulosa cells (GCs) and cumulus-oocyte complexes (COCs) from these animals, and to relate these findings to the developmental potential of oocytes. Plasma, GCs and COCs were recovered from 32 heifers on day 5 of a synchronised oestrous cycle for FA analyses. Oocytes were also recovered on days 10 and 15 of the same cycle after short-term ovarian stimulation (FSH + GnRH), and matured, fertilised and cultured to the blastocyst stage in vitro. High levels of dietary starch increased $(P<0.01)$ plasma insulin but, together with dietary FA, reduced $(P<0.05)$ blastocyst yields in low, but not in moderate, BCS heifers. Dietinduced alterations to the FA content of plasma were less apparent in GCs and COCs. In summary, although dietary lipids increased the FA content of COCs, the selective uptake of saturated FAs at the expense of mainly polyunsaturated FAs within the follicular compartment ensured that the FA composition of COCs was largely unaffected by diet. However, the concentration of saturated FAs within COCs was inherently high, and so further increases in FA content may have impaired postfertilisation development. The data establish a robust nutritional framework for more detailed studies into the mechanistic effects of dietary composition on the post-fertilisation developmental potential of oocytes.

Reproduction (2006) 131 247-258
\end{abstract}

\section{Introduction}

Nutritional status is a major factor determining reproductive success in mammals and can act at various levels within the hypothalamus-pituitary-ovarian axis to regulate follicular development and ovulation (Cameron 1996, Schneider et al. 2000, Armstrong et al. 2003). While there is a considerable body of data describing the effects of nutritional status on the central mechanisms governing gonadotrophin release (Schneider 2004), much less is known about the direct effects of nutrition on the follicle-enclosed oocyte, and the consequences that this might have for post-fertilisation development. Studies with ruminants have, to date, tended to focus on the effects of plane of nutrition (normally expressed as multiples of the energy requirements for body maintenance) in moderately obese animals (e.g. Nolan et al. 1998, Armstrong et al. 2001). We recently demonstrated that plane of nutrition can interact with the degree of heifer body fatness (body condition score) to determine the postfertilisation developmental potential of bovine oocytes (Adamiak et al. 2005). The current work extends these studies to investigate the effects of altering the nature and level of carbohydrates and fatty acids in the diet.

Increasing the proportion of starch within the ruminant diet alters the molar proportions of the principal shortchain volatile fatty acids, favouring an increase in propionate production within the rumen and glucose synthesis within the liver (Demigne et al. 1988). Consequently, in addition to increasing glucose, high-starch diets increase mean basal and postprandial plasma insulin concentrations in ruminants (Vernon \& Peaker 1983). This in turn can lead to improvements in oocyte and embryo quality, although our recent evidence indicates that high planes of nutrition in moderately obese animals lead to hyperinsulinaemia and impaired oocyte quality (Adamiak et al. 2005). 
The inclusion of rumen bypass fatty acids (such as calcium soaps of palm oil fatty acids) within ruminant diets has been shown to improve fertility, with beneficial effects on whole-animal energy metabolism, and reported actions on the ovarian follicle and corpus luteum (Mattos et al. 2000). In contrast, although the fatty acid composition of oocytes across a number of mammalian species has been chronicled (e.g. McEvoy et al. 2000), little is known about the uptake of specific fatty acids by the follicle-enclosed oocyte, how this may be altered by maternal nutrition and the consequences that this might have for post-fertilisation development. For example, although the feeding of a high polyunsaturated fatty acid (PUFA) diet to pubertal ewe lambs has been found to increase the number of ovarian follicles and improve oocyte quality (by morphological assessment), the PUFA content $(\% \mathrm{w} / \mathrm{w})$ of these oocytes was not affected, and post-fertilisation development was not determined (Zeron et al. 2002).

The primary objective of the present study, therefore, was to assess the interactive effects of carbohydrate type (fibre vs starch) and fatty acid supplementation in moderately lean (low body condition) and fat (moderate body condition) heifers on the post-fertilisation developmental potential of oocytes recovered by ultrasound guided transvaginal follicular aspiration. A secondary objective was to compare the fatty acid composition of plasma to that of granulosa cells and cumulus-oocyte complexes from these animals, and to relate these findings to the post-fertilisation developmental potential of these oocytes.

\section{Materials and Methods}

The experiment described in this paper was reviewed by the Animal Experiments Committee of the Scottish Agricultural College and was conducted under the auspices of, and in accordance with, the requirements of the Home Office Animals (Scientific Procedures) Act 1986.

\section{Animals, dietary treatments and experimental design}

Thirty-two beef $x$ dairy heifers of approximately 20 months of age and with an average initial weight (mean \pm S.E.M.) of $396.9 \pm 4.1 \mathrm{~kg}$ were used. All animals were accommodated in individual pens on slatted floors. Immediately prior to the experiment, the body-condition scores (BCS) (six-point scale of Lowman et al. 1976, where $0=$ lean and $5=$ obese) of these animals were determined, and they were allocated accordingly to either a low or moderate-BCS group. Animals within each BCS group were then allocated at random to one of four dietary treatments: high fibre $(F)$ either with or without $6 \%$ Megalac (calcium soaps of palm oil fatty acids, $440 \mathrm{~g} / \mathrm{kg}$ palmitic acid (C16:0), $400 \mathrm{~g} / \mathrm{kg}$ oleic acid (C18:1, n-9), $95 \mathrm{~g} / \mathrm{kg}$ linoleic acid (C18:2, n-6), $50 \mathrm{~g} / \mathrm{kg}$ stearic acid (C18:0) and $15 \mathrm{~g} / \mathrm{kg}$ myristic acid (C14:0); Volac
International, Royston, UK), or high starch (S) again either with or without $6 \%$ Megalac. This resulted in a $2 \times 2 \times 2$ factorial arrangement with animals of low or moderate BCS, offered diets containing predominantly one of two types of carbohydrate (fibre vs starch), either with or without Megalac, replicated four times. Alterations to the source of fermentable carbohydrate and the lipid content of the diets inevitably led to differences in energy density (MJ metabolisable energy (ME)/kg dry matter) (Table 1). Concentrate levels for each of the four dietary treatments, therefore, were adjusted to ensure that each animal received $1000 \mathrm{~kJ} \mathrm{ME} / \mathrm{kg}$ live weight ${ }^{0.75} /$ day, equivalent to approximately twice the maintenance energy requirements for this type of animal (AFRC 1993), offered as two meals (at 0800 and $1600 \mathrm{~h}$ ). This feeding level accounted for the intake of barley straw, which was fixed at $2 \mathrm{~kg}$ fresh material daily. These diets were supplemented (80 g/head per day) with a proprietary mineral and vitamin supplement (Norvite, Insch, UK) containing 18\% Ca, 12\% $\mathrm{Na}, 0.2 \% \mathrm{Cu}, 0.02 \% \mathrm{Co}, 0.1 \% \mathrm{Mn}, 0.3 \% \mathrm{Zn}, 0.01 \%$ I, $0.003 \% \mathrm{Se}, 400000 \mathrm{lU} / \mathrm{kg}$ vitamin A, $80000 \mathrm{lU} / \mathrm{kg}$ vitamin $\mathrm{D}_{3}$ and $600 \mathrm{IU} / \mathrm{kg}$ vitamin E. Animals were weighed every 2 weeks and feeding levels adjusted accordingly. The experimental diets were introduced 1 week prior to the initial period of oestrous synchronisation (Fig. 1).

Table 1 Composition of concentrates and chemical analysis of feeds.

\begin{tabular}{|c|c|c|c|c|}
\hline \multirow{2}{*}{$\begin{array}{l}\text { Principal carbohydrate } \\
\text { Megalac (\%) }\end{array}$} & \multicolumn{2}{|c|}{ Fibre } & \multicolumn{2}{|c|}{ Starch } \\
\hline & 0 & 6 & 0 & 6 \\
\hline \multicolumn{5}{|l|}{ (a) Ingredient (g/kg) } \\
\hline Wheat & - & - & 450 & 500 \\
\hline Maize & - & - & 200 & 200 \\
\hline Malt culms & - & 62 & 14 & 146 \\
\hline Wheat feed & 219 & 250 & 250 & - \\
\hline Oat feed & 200 & 200 & 28 & 18 \\
\hline Sugar beet pulp & 489 & 307 & - & - \\
\hline Rapeseed meal & - & 33 & - & 18 \\
\hline Urea & 12 & 8 & 8 & 8 \\
\hline Molasses & 80 & 80 & 50 & 50 \\
\hline \multirow{2}{*}{ Megalac } & - & 60 & - & 60 \\
\hline & 1000 & 1000 & 1000 & 1000 \\
\hline \multicolumn{5}{|c|}{ (b) Chemical analysis ${ }^{\ddagger}$ - concentrate } \\
\hline Dry matter, g/kg & 864 & 863 & 857 & 866 \\
\hline $\mathrm{ME}, \mathrm{MJ} / \mathrm{kg} \mathrm{DM}$ & 11.3 & 12.1 & 13.1 & 14.2 \\
\hline Crude protein, g/kg DM & 139 & 140 & 153 & 149 \\
\hline NDF, g/kg DM & 361 & 380 & 170 & 143 \\
\hline Starch, g/kg DM & 210 & 187 & 512 & 495 \\
\hline AHEE, g/kg DM & 24 & 67 & 35 & 71 \\
\hline \multicolumn{5}{|l|}{ (c) Chemical analysis ${ }^{\ddagger}-$ straw } \\
\hline Dry matter, g/kg & & & 860 & \\
\hline $\mathrm{ME}, \mathrm{MJ} / \mathrm{kg} \mathrm{DM}$ & & & 5.6 & \\
\hline Crude protein, g/kg DM & & & 31 & \\
\hline NDF, g/kg DM & & & 855 & \\
\hline Starch, g/kg DM & & & 11 & \\
\hline AHEE, g/kg DM & & & 18 & \\
\hline
\end{tabular}

${ }^{\ddagger}$ DM: dry matter; ME: metabolisable energy; NDF: neutral detergent fibre; AHEE: acid hydrolysed ether extract. 


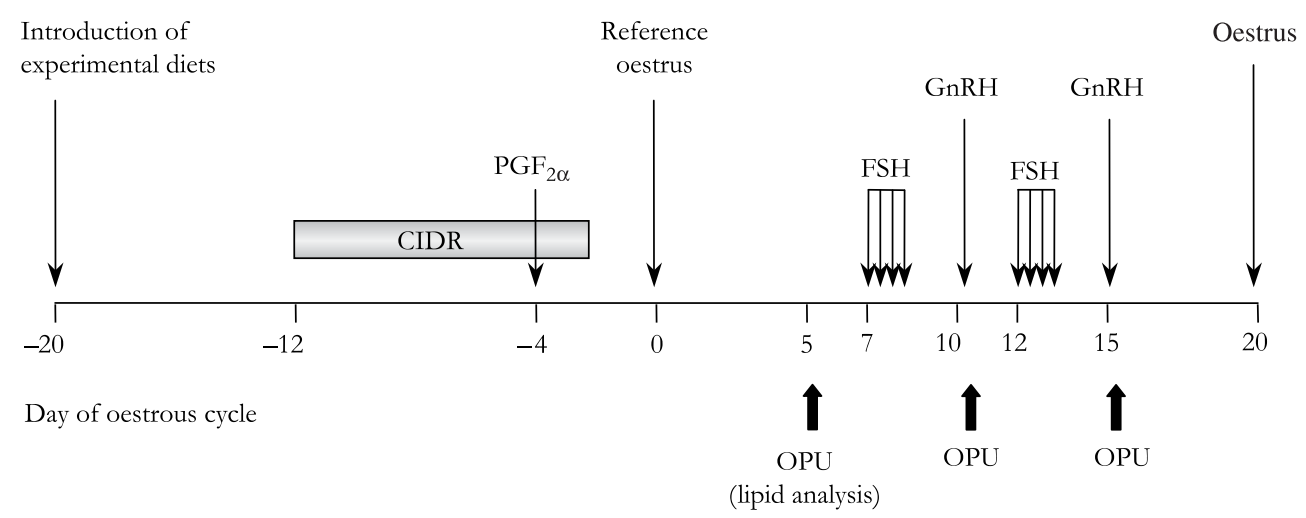

Figure 1 Schematic representation of oestrous synchronisation (controlled internal drug-release dispenser (CIDR) plus prostaglandin $\mathrm{F}_{2 \alpha}\left(\mathrm{PGF}_{2 \alpha}\right)$ ), ovarian stimulation (four doses of FSH administered over $36 \mathrm{~h}$ ) and follicular aspiration (ovum pick-up (OPU)). A GnRH agonist was administered $6 \mathrm{~h}$ before the second and third sessions of OPU, and a $\mathrm{PGF}_{2 \alpha}$ analogue was administered $48 \mathrm{~h}$ after the last of these sessions. See text for details.

\section{Oestrous synchronisation, oocyte recovery and follicular growth}

A reference oestrus was established with a 10-day progesterone-releasing device, CIDR (controlled internal drug-release dispenser) (SmithKline Beecham, Tadworth, UK), containing $1.9 \mathrm{~g}$ progesterone. A prostaglandin $\mathrm{F}_{2 \alpha}$ agonist (luprositol $15 \mathrm{mg}$; Prosolvin, Intervet, Cambridge, UK) was administered intramuscularly 8 days after CIDR insertion. Heifers were predicted to be in oestrus 2 days after CIDR removal (day $0=$ day of reference oestrus) (Fig. 1).

Animals were subjected to ultrasound guided transvaginal follicular aspiration (ovum pick-up) (OPU)), as described by Goodhand et al. (1999), on day 5 of the subsequent oestrous cycle, and harvested oocytes and granulosa cells were used for fatty acid analysis (described later). The ovarian stimulation programme used to collect oocytes for in vitro culture was based on that of Blondin et al. (2002) with the following modifications. Four constant doses of follicle-stimulating hormone (FSH) (total amount equivalent to $9 \mathrm{mg}$ NIADDK-oFSH-17; Ovagen, ICP, Auckland, New Zealand) were administered intramuscularly at 12 -h intervals over a 36 -h period commencing $48 \mathrm{~h}$ after follicular aspiration on day 5 (Fig. 1). There followed a 40-h 'coasting' period before OPU, during which no further FSH was administered. A gonadotrophinreleasing hormone $(\mathrm{GnRH})$ analogue $(0.012 \mathrm{mg}$ Buserelin; Receptal, Hoechst Animal Health, Milton Keynes, UK) was administered intravenously $6 \mathrm{~h}$ before the second and third sessions of OPU. Oocytes from these stimulated ovaries were selected for in vitro maturation, fertilisation and culture to the blastocyst stage. The rationale for adopting this protocol was to create developmentally competent oocytes representative of those within preovulatory follicles. It was derived from the concept that the ability of the oocyte to develop after fertilisation is acquired before the onset of meiosis (Sirard 2001) and, in the context of the current study, follicular aspiration. Central to this concept is the withdrawal of FSH for
36-48 $\mathrm{h}$ before oocyte retrieval, so inducing early atresia in follicles, followed by luteinising hormone (LH) (or $\mathrm{GnRH}$ ) treatment several hours before aspiration, a treatment which attempts to mimic the periovulatory endocrine milieu.

At the beginning of each OPU session, heifers were sedated by $28 \mathrm{mg}$ xylazine hydrochloride (Rompun; Bayer, Leverkusen, Germany) administered i.m. before epidural anaesthesia (150 mg lignocaine hydrochloride) (Locovetic; Bimeda, Anglesey, UK) between the first and second coccygeal vertebrae. A $5 \mathrm{MHz}$ curvilinear transducer (Aloka SSD-500 V; BCF, Livingstone, UK) was inserted vaginally, and all visible follicles over $2 \mathrm{~mm}$ diameter were categorised by diameter before aspiration. All visible follicles were then aspirated with a single lumen needle (20 gauge) at a vacuum pressure of $70 \mathrm{~mm} \mathrm{Hg}$ into conical tubes containing $5 \mathrm{ml}$ warm PBS supplemented with $0.1 \%$ $w / v$ fatty acid-free BSA and antibiotics.

Blood samples were collected before the early morning meal on days 0 (oestrus), 5, 8, 10 (OPU 2), 13, 15 (OPU 3 ), 18, 19 and 20 (oestrus) by jugular venipuncture into EDTA-treated tubes on ice. Plasma was harvested from these samples within $30 \mathrm{~min}$ of collection and stored at $-20^{\circ} \mathrm{C}$ until analysis.

\section{In vitro embryo production (IVP)}

Full details of these procedures were given previously (Sinclair et al. 2000, Adamiak et al. 2005), and only a brief summary is provided here. All reagents and media used in the experiment were obtained from Sigma unless otherwise stated. Animal identity was retained throughout. Tubes containing aspirants were transported in a polystyrene box (at $37^{\circ} \mathrm{C}$ ) to the laboratory, and aspirants were filtered through a sterile, $70 \mu \mathrm{m}$ nylon gauze (BD Falcon, Bedford, MA, USA) rinsed with PBS supplemented with $0.2 \% \mathrm{w} / \mathrm{v}$ fatty acid-free BSA and antibiotics. Cumulus-oocyte complexes (COCs) were graded on a four-point scale by the number of compact cumulus cell layers and granulation of 
the oocyte cytoplasm, as described by Goodhand et al. (1999). Selected (grades 1-3) COCs were matured in $50 \mu \mathrm{l}$ drops of maturation medium (bicarbonate-buffered TCM199 with Earle's salts and supplemented with 0.4\% $\mathrm{w} / \mathrm{v}$ fatty acid-free BSA, $10 \mu \mathrm{g} / \mathrm{ml} \mathrm{FSH}, 10 \mu \mathrm{g} / \mathrm{ml} \mathrm{LH}$ and antibiotics) with granulosa cell (GC) monolayers $(\leq 20$ oocytes/drop), overlaid with mineral oil. These monolayers were prepared as described previously (Adamiak et al. 2005). Oocytes were matured for $24 \mathrm{~h}$ at $38.8^{\circ} \mathrm{C}$ in a humidified atmosphere of $5 \% \mathrm{CO}_{2}$ in air.

Frozen semen from a single bull was thawed at $37^{\circ} \mathrm{C}$ and layered $(85 \mu \mathrm{l})$ under $1 \mathrm{ml}$ modified, calcium-free Tyrode's albumin lactate pyruvate medium (TALP) in conical tubes for a swim-up procedure, as described previously (Adamiak et al. 2005). Motile spermatozoa were counted and added in a maximum of $4 \mu \mathrm{l}$ capacitation media to a $46 \mu \mathrm{l}$ drop of fertilisation media containing matured oocytes (up to 20 per drop), to give a final concentration of $1 \times 10^{6}$ motile spermatozoa $/ \mathrm{ml}$ fertilisation media. Fertilisation medium was modified TALP supplemented with (in $\mathrm{nmol} / \mathrm{ml}$ ) 0.2 penicillamine, 0.1 hypotaurine and 0.02 epinephrine, with $0.6 \% \mathrm{w} / \mathrm{v}$ fatty acid-free BSA, $30 \mu \mathrm{g} / \mathrm{ml}$ heparin and antibiotics. The oocytes and spermatozoa were incubated in $50 \mu \mathrm{l}$ drops under mineral oil for $22 \mathrm{~h}$ at $38.8^{\circ} \mathrm{C}$ in a humidified atmosphere of $5 \% \mathrm{CO}_{2}$ in air. Putative zygotes were cultured in groups of up to 20 zygotes per $30 \mu l$ drops of synthetic oviductal fluid medium (Tervit et al. 1972), containing (in $\mu \mathrm{mol} / \mathrm{ml}$ ) $25 \mathrm{NaHCO}_{3}, 108 \mathrm{NaCl}, 7.2 \mathrm{KCl}$, $1.7 \mathrm{CaCl}_{2}, 1.2 \mathrm{KH}_{2} \mathrm{PO}_{4}, 0.5 \mathrm{MgCl}_{2}, 1.5$ glucose, 3.3 sodium pyruvate, 33 sodium lactate and 1 L-glutamine, supplemented with $0.3 \% \mathrm{w} / \mathrm{v}$ fatty acid-free BSA, $1 \% \mathrm{v} / \mathrm{v}$ non-essential amino acids, and $2 \% \mathrm{v} / \mathrm{v}$ essential amino acids and antibiotics. Putative zygotes were incubated in a humidified atmosphere of $5 \% \mathrm{CO}_{2}, 5 \% \mathrm{O}_{2}$, and $90 \%$ $\mathrm{N}_{2}$ at $38.8^{\circ} \mathrm{C}$, and droplets were renewed every $48 \mathrm{~h}$. On day 2 of development (day $0=$ in vitro fertilisation), the cleavage rate was recorded, and cleaved zygotes were then cultured in $30 \mu \mathrm{l}$ microdrops until day 8 .

\section{Embryo development and TUNEL analysis}

Blastocyst yield and developmental stage were recorded on day 8 after in vitro fertilisation. Blastocysts were then washed and fixed in $4 \% \mathrm{w} / \mathrm{v}$ paraformaldehyde and stored in a cold room for up to 1 week in preparation for cell counts and TUNEL analysis (ApopTag staining kit, Intergen, Purchase, NY, USA). Briefly, after washing in PBS with $0.1 \% \mathrm{w} / \mathrm{v}$ polyvinylpyrrolidone (PVP), embryos were permeabilised in $1 \% \mathrm{w} / \mathrm{v}$ saponin for $1 \mathrm{~h}$ at room temperature. The embryos were then washed in $20 \mu \mathrm{l}$ drops of PBS with $0.1 \% \mathrm{w} / \mathrm{v}$ PVP and $0.1 \% \mathrm{v} / \mathrm{v}$ Tween 20 (PPT), incubated for $10 \mathrm{~min}$ in equilibration buffer, transferred to $20 \mu \mathrm{l}$ drops of working strength TdT enzyme and incubated for $1 \mathrm{~h}$ in a humidified chamber at $37^{\circ} \mathrm{C}$. The reaction was terminated, the embryos washed again in PPT and transferred to $20 \mu \mathrm{l}$ drops of working strength antidigoxigenin conjugate, and incubated in a darkened, humidified chamber for $1 \mathrm{~h}$ at room temperature. After washing in PPT, the embryos were transferred to $20 \mu \mathrm{l}$ drops of Hoechst $33324(10 \mu \mathrm{g} / \mathrm{ml}$ in $2.3 \% \mathrm{w} / \mathrm{v}$ sodium citrate) and incubated for $15 \mathrm{~min}$ at room temperature. Finally, the embryos were mounted on silanised slides, overlaid with $30 \mu \mathrm{l}$ Citifluor solid mounting medium (Agar Scientific, Stansted, UK), and visualised by fluorescence microscopy. Cell number and the proportion of TUNEL-positive cells were promptly recorded.

\section{Lipid analysis}

Cumulus-oocyte complexes from two animals per treatment were pooled to ensure a minimum of five COCs per replicate. This also permitted the grading of COCs within each pair according to the amount of surrounding cumulus cells. Poor-quality COCs (grades 3-4) with few cumulus cells were analysed separately from good-quality COCs (grades 1-2), which had several layers of cumulus cells (Goodhand et al. 1999). The COCs were washed several times in SOF (containing $0.4 \% \mathrm{w} / \mathrm{v}$ fatty acid free-BSA) before transfer in $5 \mu \mathrm{l}$ media into a test tube containing $25 \mathrm{ml}$ chloroform:methanol (2:1 v:v solution) and $137.5 \mathrm{mg}$ internal standard (pentadecanoic acid, C15:0). Granulosa cells from each animal were washed twice in PBS/BSA by centrifugation before lipid extraction. Total lipid was extracted as described by Christie (1982). The esterified lipid fractions were subjected to transmethylation by refluxing with methanol:toluene:sulphuric acid (20:10:1 v:v) (Christie et al. 1970), extracted into a final volume of $50 \mu \mathrm{l}$ hexane and assayed in duplicate. The fatty acid methyl esters were injected via a CP8200 autosampler (Varian Analytical Instruments, Walton-onThames, UK), into a $30 \mathrm{~mm}, 0.25 \mathrm{~mm}$ internal diameter, $0.25 \mu \mathrm{m}$ film thickness, HP-225 capillary column (Hewlett Packard, Stockport, UK). Injection volume was $2 \mu$ l by the spitless method. Peak areas were determined with a Varian Star Chromatography Workstation (Version 5.5; Varian Analytical Instruments), identified with reference to a known standard (37-Component Mix; Supelco, Poole, UK) and quantified by the internal standard method.

Due to the scarcity of biological material, it was impracticable to set up appropriate quality control for the COCs. However, the recovery of triglyceride (trinonadecanoin, 19:0) and phospholipid (phosphatidylcholine, diheptadecanoyl, 17:0) was monitored throughout. Recoveries (16 observations) were $96.8 \pm 2.36 \%$ and $97.5 \pm 2.32 \%$ for triglyceride and phospholipid respectively, which did not differ $(P>0.05)$ from $100 \%$. Furthermore, there was no significant difference (paired $t$-test) between recoveries of triglyceride and phospholipid.

\section{Hormone analysis}

Plasma insulin concentrations were determined by ${ }^{125} \mathrm{I}$ labelled insulin double-antibody RIA by the method of 
Starr et al. (1979). The assay was modified to use porcine insulin (I-3505, 24 IU/mg) obtained from Sigma and guinea-pig antiporcine insulin, normal guinea-pig serum and sheep anti-guinea-pig IgG donated by the Scottish Antibody Production Unit, Law Hospital, Carluke, UK. The

${ }^{125}$ I-labelled porcine insulin solution was prepared by the chloramine T method (Greenwood et al. 1963). The minimum detection limit of the assay (defined at $\mathrm{ED}_{85}$ ) was $2.6 \mu \mathrm{lU} / \mathrm{ml}$. The interassay coefficients of variation for low, medium and high controls were $10.0 \%, 7.9 \%$ and $10.3 \%$ respectively, and corresponding intra-assay coefficients of variation were $6.7 \%, 7.9 \%$ and $7.1 \%$.

Plasma insulin-like growth factor (IGF)-I concentrations were determined by a ${ }^{125}$ I-labelled IGF-I double-antibody RIA based on the method of Armstrong et al. (1990). Serum IGF-I was first separated from its binding proteins by acid gel HPLC by the method of Owens et al. (1990). The RIA used recombinant human IGF-I, anti-human IGF-I polyclonal antiserum (rabbit) both obtained from GroPep (Adelaide, Australia), normal rabbit serum and donkey anti-rabbit IgG obtained from Diagnostics Scotland (Law Hospital). The ${ }^{125}$ I-labelled IGF-I solution was prepared by the chloramine T method (Greenwood et al. 1963). All samples analysed for IGF-I concentrations were processed in a single assay with a detection limit of $12.5 \mathrm{ng} / \mathrm{ml}$ where the coefficients of variation for low- and highquality controls were 11.7 and $8.4 \%$ respectively.

Plasma leptin concentrations were determined in duplicate by the method of Blache et al. (2000). The primary antibody (emu anti-recombinant ovine/bovine leptin), normal emu serum and sheep antiemu serum were both provided by Dr Blache (University of Western Australia). Ovine leptin (supplied by Dr Keisler, University of Missouri, USA) was iodinated in-house as described above. The detection limit for leptin concentration was $0.2 \mathrm{ng} / \mathrm{ml}$, and the interassay coefficients of variation for low, medium and high controls were $13.0 \%, 9.7 \%$ and $10.5 \%$ respectively. Corresponding intra-assay coefficients of variation were $12.8 \%, 9.9 \%$ and $10.3 \%$ respectively.

Plasma progesterone was analysed without prior extraction by a ${ }^{125}$ I-progesterone double-antibody RIA (McNeilly \& Fraser 1987). The assay was modified and validated to enable the use of a rabbit anti-progesterone first antibody, donkey antirabbit IgG and normal rabbit serum, which were donated by the Scottish Antibody Production Unit, Carluke, UK. The sensitivity of the assay at $\mathrm{ED}_{80}$ was $0.62 \mathrm{ng} / \mathrm{ml}$. The interassay coefficients of variation for low, medium and high controls were $13.0 \%, 9.7 \%$ and $10.5 \%$ respectively, and corresponding intra-assay coefficients of variation were $12.8 \%, 9.9 \%$ and $10.3 \%$ respectively.

\section{Data analysis}

Changes in plasma hormone concentrations were analysed by repeated measures ANOVA within GenStat 6 (Genstat 2002), where BCS (low vs moderate), carbohydrate source (fibre vs starch), fatty acid inclusion (0\% vs 6\%) and interactions between these factors formed the between-animal stratum; sample day, BCS, carbohydrate source and fatty acid inclusion formed the within animal $\times$ day stratum. Similarly, the fatty acid composition of plasma, granulosa cells and COCs were analysed by repeated measures ANOVA. In the case of COCs, however, COC grade (poor vs good) replaced sample day in the model. Data presented are predicted means with either appropriate standard errors of differences or standard errors of means. Oocyte recovery and in vitro embryo production data (i.e. oocytes cleaved and day-8 blastocyst yields) were analysed by generalised linear models assuming binomial errors with logit link functions within the same statistical package. Terms fitted to the model were animal, BCS, carbohydrate source, fatty acid inclusion and OPU session. Comparisons between means were conducted by analysis of deviance. Data are presented as predicted means from these models.

\section{Results}

\section{Live weight and body condition}

Mean ( \pm S.E.M.) live weight and BCS were lower $(P<0.001)$ at the beginning of the experimental period for heifers allocated to the low- than the moderate-BCS group $(382.2 \pm 4.86$ vs $411.7 \pm 4.19 \mathrm{~kg}$; and $2.5 \pm 0.09$ vs $3.0 \pm 0.06$ units). However, neither BCS nor dietary composition (i.e. carbohydrate source and fatty acid supplementation) affected the extent of live weight and BCS gained during the experimental period. Heifers gained, on average, $1.29 \pm 0.07 \mathrm{~kg} /$ day and $0.31 \pm 0.12$ units BCS over the 40-day period.

\section{Endocrinology}

Plasma progesterone concentrations peaked on day 15 of the oestrous cycle and, for low-BCS heifers, were greater $(P<0.01)$ when Megalac was included in the diet $(14.4$ vs $8.6 \mathrm{ng} / \mathrm{ml}$; S.E.D. $=1.56)$. There was an interaction between carbohydrate source and Megalac, indicating that the inclusion of rumen bypass fatty acids increased peak plasma progesterone concentrations in low-BCS heifers offered the high-fibre, but not the high-starch, diet (Table 2a).

Metabolic hormone concentrations were determined over a 3-day period leading up to oestrus (day 20) (Fig. 1). On the day of oestrus, mean concentrations of plasma insulin were greater $(P<0.01)$ for heifers in moderate than low BCS (17.06 vs 12.84; S.E.D. $=1.49$ ). Plasma insulin concentrations averaged over this 3-day period were greater $(P<0.01)$ for low-BCS heifers on the high-starch than on the high-fibre diet $(16.7$ vs $10.8 \mu \mathrm{lU} / \mathrm{ml}$; S.E.D. $=1.47)$ (Table 2). Similarly, plasma insulin concentrations were greater $(P<0.01)$ for moderate-BCS heifers on the high-starch than high-fibre diet but, in these animals, only on the day of oestrus (20.4 vs $13.8 \mu \mathrm{lU} / \mathrm{ml}$ for 
Table 2 Peak plasma progesterone concentrations (coinciding with day 15 (third OPU) of the oestrous cycle), and plasma insulin, IGF-I and leptin concentrations averaged over the last 3 days leading up to the second induced oestrous (day 20).

\begin{tabular}{|c|c|c|c|c|c|c|c|c|}
\hline \multirow{2}{*}{$\begin{array}{l}\text { Principal carbohydrate (C) } \\
\text { Megalac (\%) (FA) }\end{array}$} & \multicolumn{2}{|c|}{ Fibre } & \multicolumn{2}{|c|}{ Starch } & \multirow[b]{2}{*}{ S.E.D. } & \multicolumn{3}{|c|}{ Significance of effect } \\
\hline & 0 & 6 & 0 & 6 & & $\mathrm{C}$ & FA & CXFA \\
\hline \multicolumn{9}{|l|}{ (a) Low BCS } \\
\hline No of heifers & 4 & 4 & 4 & 4 & & & & \\
\hline Peak progesterone $(\mathrm{ng} / \mathrm{ml})$ & $6.7^{\mathrm{a}}$ & $16.0^{\mathrm{b}}$ & $10.5^{\mathrm{ab}}$ & $12.8^{\mathrm{b}}$ & 2.20 & & $<0.01$ & $<0.05$ \\
\hline Insulin $(\mu \mathrm{IU} / \mathrm{ml})$ & $11.2^{\mathrm{a}}$ & $10.5^{\mathrm{a}}$ & $16.1^{\mathrm{b}}$ & $17.2^{\mathrm{b}}$ & 1.47 & $<0.01$ & & \\
\hline IGF-I (ng/ml) & 232.7 & 225.5 & 275.0 & 234.2 & 35.08 & & & \\
\hline Leptin (ng/ml) & 2.4 & 2.1 & 1.8 & 2.7 & 0.44 & & & $<0.06$ \\
\hline \multicolumn{9}{|l|}{ (b) Moderate BCS } \\
\hline No. of heifers & 4 & 4 & 4 & 4 & & & & \\
\hline Peak progesterone $(\mathrm{ng} / \mathrm{ml})$ & 14.5 & 9.5 & 13.1 & 13.9 & 2.98 & & & \\
\hline Insulin $(\mu \mathrm{IU} / \mathrm{ml})$ & 14.3 & 13.6 & 18.2 & 15.9 & 2.60 & & & \\
\hline IGF-I (ng/ml) & 232.5 & 221.2 & 266.8 & 244.6 & 21.88 & & & \\
\hline Leptin (ng/ml) & 4.4 & 5.4 & 4.9 & 3.7 & 0.93 & & & \\
\hline
\end{tabular}

Means within a row with different superscripts are significantly different $(P<0.05)$.

the high-starch and high-fibre diets respectively; S.E.D. $=2.6$ ). There was an indication that plasma IGF-I concentrations at oestrus were also greater $(P=0.05)$ for moderate-BCS heifers offered the high-starch than highfibre diet $(261.0$ vs $226.0 \mathrm{ng} / \mathrm{ml}$ for the high-starch and high-fibre diets respectively; S.E.D. $=15.84$ ), but this observation was not consistent for low-BCS heifers. Plasma leptin concentrations were greater $(P<0.001)$ for heifers in moderate than low BCS (4.6 vs $2.2 \mathrm{ng} / \mathrm{ml}$; S.E.D. $=0.37$ ), but were not significantly influenced by dietary composition.

\section{Oocyte and embryo development in vitro}

The number of follicles aspirated was not affected by experimental treatment but was greater $(P<0.001)$ for each of the two FSH/GnRH stimulated cycles of OPU per animal than for the non-stimulated cycle $(25.9 \pm 1.87$ vs $15.4 \pm 1.15$ follicles). However, the number of oocytes recovered did not differ between stimulated (12.1 \pm 0.92$)$ and non-stimulated $(11.6 \pm 1.00)$ cycles. In spite of this, the percentage of grades 1-2 oocytes recovered was greater $(P<0.001)$ for stimulated than non-stimulated ovaries $(62.4 \pm 2.77 \%$ vs $42.5 \pm 2.93 \%)$. Furthermore, compared with COCs from non-stimulated heifers after slaughter at the end of the current study (data not presented), ovarian stimulation significantly $(P<0.05)$ enhanced both cleavage rates and blastocyst yields in vitro $(74 \%$ vs $64 \%$ and $32 \%$ vs $18 \%$ for cleavage rates and blastocysts of cleaved oocytes respectively).

There was a suggestion that cleavage rate (oocytes cleaved of matured oocytes) was greater for oocytes recovered from low- than moderate-BCS heifers $(75.7 \pm 2.1$ vs $68.0 \pm 2.8 \% ; P=0.05)$ and from heifers offered the

Table 3 Embryo development following maturation, fertilisation and culture in vitro.

\begin{tabular}{|c|c|c|c|c|}
\hline \multirow{2}{*}{$\begin{array}{l}\text { Principal carbohydrate }(\mathrm{C}) \\
\text { Megalac }(\%)(\mathrm{FA})\end{array}$} & \multicolumn{2}{|c|}{ Fibre } & \multicolumn{2}{|c|}{ Starch } \\
\hline & 0 & 6 & 0 & 6 \\
\hline \multicolumn{5}{|l|}{ (a) Low BCS } \\
\hline No. of heifers & 4 & 4 & 4 & 4 \\
\hline Oocytes matured $(n)$ & $11.2 \pm 3.6$ & $14.4 \pm 4.1$ & $15.2 \pm 4.2$ & $10.1 \pm 3.5$ \\
\hline Oocytes cleaved $(n)$ & $8.6 \pm 2.6$ & $11.5 \pm 3.0$ & $10.9 \pm 3.0$ & $7.5 \pm 2.5$ \\
\hline Cleaved of matured (\%) & $76.7 \pm 4.8$ & $80.0 \pm 4.0$ & $71.1 \pm 4.4$ & $74.1 \pm 5.2$ \\
\hline Blastocysts $(n)$ & $4.6 \pm 1.4$ & $3.9 \pm 1.3$ & $3.5 \pm 1.2$ & $1.6 \pm 0.8$ \\
\hline Blastocyst yield (\%) & $53.6^{\mathrm{a}} \pm 7.9$ & $33.7^{b} \pm 6.5$ & $32.2^{b} \pm 6.6$ & $21.7^{b} \pm 7.0$ \\
\hline Cell number & $111.3^{\mathrm{a}} \pm 5.3$ & $131.7^{b} \pm 5.7$ & $154.2^{\mathrm{C}} \pm 6.2$ & $123.2^{\mathrm{ab}} \pm 6.4$ \\
\hline TUNEL-positive cells (\%) & $4.6 \pm 1.2$ & $4.8 \pm 1.1$ & $3.5 \pm 0.9$ & $3.1 \pm 1.1$ \\
\hline \multicolumn{5}{|l|}{ (b) Moderate BCS } \\
\hline No. of heifers & 4 & 4 & 4 & 4 \\
\hline Oocytes matured $(n)$ & $11.9 \pm 3.7$ & $13.1 \pm 3.9$ & $10.2 \pm 3.5$ & $9.5 \pm 3.3$ \\
\hline Oocytes cleaved $(n)$ & $7.6 \pm 2.5$ & $10.2 \pm 2.9$ & $6.6 \pm 2.3$ & $6.1 \pm 2.2$ \\
\hline Cleaved of matured (\%) & $64.2 \pm 5.3$ & $78.1 \pm 4.3$ & $64.6 \pm 5.7$ & $64.5 \pm 5.9$ \\
\hline Blastocysts $(n)$ & $1.0 \pm 0.6$ & $3.5 \pm 1.2$ & $2.0 \pm 0.9$ & $2.1 \pm 0.9$ \\
\hline Blastocyst yield (\%) & $13.1 \pm 5.7$ & $34.2 \pm 6.9$ & $30.2 \pm 8.3$ & $34.7 \pm 9.0$ \\
\hline Cell number & $105.1^{\mathrm{ac}} \pm 5.9$ & $134.5^{\mathrm{b}} \pm 5.8$ & $119.4^{\mathrm{C}} \pm 6.3$ & $104.7^{\mathrm{a}} \pm 5.1$ \\
\hline TUNEL-positive cells (\%) & $4.2 \pm 1.4$ & $3.0 \pm 0.9$ & $3.3 \pm 1.2$ & $5.0 \pm 1.3$ \\
\hline
\end{tabular}

Means within a row with different superscripts are significantly different $(P<0.05)$. 
high-fibre than the high-starch diets $(74.9 \pm 2.3 \%$ vs $68.9 \pm 2.6 \% ; P<0.1$ ) (Table 3). Heifer BCS, however, did not affect blastocyst yields (i.e. blastocysts of cleaved oocytes), but there was an interaction $(P<0.01)$ between BCS and dietary Megalac, and the suggestion of interaction $(P=0.05)$ between BCS and carbohydrate source, indicating that the inclusion of either Megalac or high levels of starch in the diet reduced blastocyst yields from oocytes recovered from low-BCS, but not moderate-BCS, heifers (Table 3). Both high-starch diets and the inclusion of Megalac in the diet reduced $(P<0.05)$ blastocyst yields in low-BCS heifers. In contrast, neither dietary constituent significantly influenced blastocyst yields in moderate-BCS heifers, although, numerically, blastocyst yields were lower $(13.1 \%)$ for oocytes derived from heifers offered the high-fibre, zero Megalac diet than for oocytes derived from heifers offered the other dietary treatments (range $=30.2-34.7 \%$ ).

The total number of blastomeres per embryo was greater $(P<0.001)$ for oocytes derived from low- than moderate-BCS heifers $(129.7 \pm 2.96$ vs $116.2 \pm 2.90)$. There were interactions $(P<0.001)$ between BCS and carbohydrate source, and carbohydrate source and Megalac on blastomere number, indicating, in the first instance, that the highest blastomere numbers were for embryos derived from low-BCS heifers offered high-starch diets and moderate-BCS heifers offered high-fibre diets and, in the second instance, for embryos derived from heifers offered the high-fibre diet with Megalac and heifers offered the high-starch diet without Megalac (Table 3). In contrast, the percentage of TUNEL-positive cells averaged $4.2 \pm 0.45 \%$ and did not differ between BCS groups nor between the dietary treatments (Table 3).

\section{Fatty acid analysis}

The total fatty acid content of plasma averaged $1120 \pm 97 \mathrm{ng} / \mathrm{ml}$ and was not affected by heifer BCS. However, the concentration of unsaturated fatty acids was greater $(P<0.05)$ for heifers with moderate than low BCS (604 vs $517 \mathrm{ng} / \mathrm{ml}$; S.E.D. = 38). This was associated with a reduction $(P<0.05)$ in monounsaturated fatty acids (211 vs $243 \mathrm{ng} / \mathrm{ml}$; S.E.D. $=14)$ and an increase $(P<0.001)$ in PUFAs (393 vs $272 \mathrm{ng} / \mathrm{ml}$; S.E.D. = 28). The former was due mainly to a reduction $(P<0.05)$ in oleic acid $(C 18: 1, n-9)$ $(181$ vs $207 \mathrm{ng} / \mathrm{ml}$; S.E.D. $=11)$, while the latter was due mainly to an increase $(P<0.001)$ in linoleic acid (C18:2, $\mathrm{n}-6)$ concentrations; however, the concentration of arachidonic acid (C20:4, n-6) was also greater $(P<0.001)$ in the fatter animals ( $23 \mathrm{vs} 9 \mathrm{ng} / \mathrm{ml}$; S.E.D. $=2$ ).

The fatty acid content of good-quality (grades 1-2) COCs with several layers of cumulus cells was greater $(P<0.01)$ than that of poor-quality COCs (grades 3-4) with few cumulus cells $(79.2$ vs $67.8 \mathrm{ng} / \mathrm{COC}$ : S.E.D. $=3.23)$. There were no other qualitative differences between these two categories of COC. In contrast to plasma, the fatty acid content of COCs was lower
$(P<0.01)$ for those recovered from moderate- than lowBCS heifers (69.18 vs $78.47 \mathrm{ng} / \mathrm{COC}$ : S.E.D. $=2.37$ ). This was due in part to a reduction in the content of saturated fatty acids, of which the reduction in stearic acid (C18:0) was greatest $(24.36$ vs $30.00 \mathrm{ng} / \mathrm{COC} ; \quad$ S.E.D. $=1.73$; $P<0.05)$, but also to a reduction $(P<0.01)$ in the content of unsaturated fatty acids (7.74 vs $11.57 \mathrm{ng} / \mathrm{COC}$; S.E.D. $=0.92)$, of which reductions in linoleic acid $(P<0.01)$ and arachidonic acid $(P<0.05)$ were greatest $(0.40$ vs $0.95 \mathrm{ng} / \mathrm{COC} ; \quad$ S.E.D. $=0.13 ; \quad$ and 0.02 vs $0.30 \mathrm{ng} /$ COC; S.E.D. $=0.09$ for linoleic and arachidonic acid respectively).

In spite of the differences in plasma and COC fatty acid composition between low- and moderate-BCS heifers, there were no interactions between the dietary treatments (i.e. fibre vs starch and $0 \%$ vs $6 \%$ Megalac) and BCS, so that the fatty acid data for both low- and moderate-BCS heifers were pooled (Table 4). Both carbohydrate source and Megalac influenced the fatty acid composition of plasma. Relative to the starch-based diets, the high-fibre diets increased $(P<0.001)$ total $(1289 \mathrm{vs} 950 \mathrm{ng} / \mathrm{ml})$ and therefore all constituent fatty acid concentrations. The proportions of fatty acids also changed in response to diet; plasma from cattle fed the starch-based diets contained proportionately more saturated (mainly palmitic acid) and monounsaturated fatty acid (mainly oleic acid) and less PUFA (mainly linoleic acid) than plasma from the fibrebased diets. Similarly, relative to the non-supplemented diets, the inclusion of $6 \%$ Megalac increased $(P<0.001)$ total (1611 vs $628 \mathrm{ng} / \mathrm{ml})$, saturated (782 vs $336 \mathrm{ng} / \mathrm{ml}$ ) and all individual fatty acid classes. Proportionately, the main effect of Megalac supplementation was to decrease the amount of saturated fatty acids (mainly stearic acid). Furthermore, the inclusion of Megalac in the diet reduced $(P<0.001)$ the ratio of saturated to unsaturated fatty acids $(0.97$ vs 1.21$)$. There was also an interaction $(P<0.001)$ between carbohydrate source and Megalac inclusion in the diet in the ratio of PUFA:monounsaturated fatty acids (1.90, 1.56, 1.03 and 1.41 for fibre and starch diets either without or with $6 \%$ Megalac respectively; S.E.D. $=0.14)$.

Differences in the fatty acid content of COCs were less marked than for plasma (Table 4). The inclusion of Megalac in the diets increased $(P<0.05)$ the total fatty acid content of COCs (77.12 vs 70.53 ng/COC; S.E.D. $=2.37$ ) but did not affect the content of saturated fatty acids. Interactions $(P<0.05)$ between carbohydrate source and Megalac inclusion indicated that Megalac in the diet increased the concentration of unsaturated (specifically monunsaturated) fatty acids in COCs from heifers offered the high-starch diet, but not the high-fibre diet. The concentrations of PUFAs within the COCs were unaffected by dietary treatments.

The fatty acid composition (\% total fatty acids) of granulosa cells and COCs differed markedly from that of plasma (Table 5). The percentage of saturated fatty acids was greater $(P<0.001)$ for COCs than for granulosa cells and plasma, while the percentage of unsaturated fatty acids 
Table 4 Effect of carbohydrate source and fatty acid supplement on the fatty acid composition of plasma and cumulus—oocyte complexes.

\begin{tabular}{|c|c|c|c|c|c|c|c|c|c|c|c|}
\hline \multirow{3}{*}{$\begin{array}{l}\text { Principal carbohydrate } \\
\text { Megalac (\%) }\end{array}$} & & \multicolumn{4}{|c|}{ Plasma } & \multirow[b]{3}{*}{ S.E.D. } & \multicolumn{4}{|c|}{ Cumulus-oocyte complexes (COC) } & \multirow[b]{3}{*}{ S.E.D. } \\
\hline & & \multicolumn{2}{|c|}{ Fibre } & \multicolumn{2}{|c|}{ Starch } & & \multicolumn{2}{|c|}{ Fibre } & \multicolumn{2}{|c|}{ Starch } & \\
\hline & & 0 & 6 & 0 & 6 & & 0 & 6 & 0 & 6 & \\
\hline No. of observations & & \multicolumn{4}{|c|}{$\mathrm{ng} / \mathrm{ml}^{8}$} & \multicolumn{5}{|c|}{$\begin{array}{c}4 \\
\mathrm{ng} / \mathrm{COC}\end{array}$} & \\
\hline Fatty acids & & & & & & & & & & & \\
\hline Total & & $754^{\mathrm{a}}$ & $1824^{\mathrm{b}}$ & $501^{\mathrm{c}}$ & $1399^{\mathrm{d}}$ & 79 & $70.2^{x}$ & $73.7^{x y}$ & $70.9^{x}$ & $80.56^{y}$ & 3.35 \\
\hline Saturated & & $392^{\mathrm{a}}$ & $868^{\mathrm{b}}$ & $281^{\mathrm{C}}$ & $696^{\mathrm{d}}$ & 35 & 61.3 & 62.8 & 61.2 & 72.7 & 4.48 \\
\hline Unsaturated & & $362^{\mathrm{a}}$ & $956^{\mathrm{b}}$ & $220^{c}$ & $702^{d}$ & 17 & $8.4^{\mathrm{x}}$ & $11.8^{\mathrm{y}}$ & $10.0^{x y}$ & $8.5^{x}$ & 1.30 \\
\hline Monounsaturated & & $127^{\mathrm{a}}$ & $378^{\mathrm{b}}$ & $110^{\mathrm{a}}$ & $295^{\mathrm{c}}$ & 19 & $6.8^{x}$ & $9.9^{y}$ & $8.3^{x y}$ & $7.8^{x}$ & 0.88 \\
\hline Polyunsaturated & & $235^{\mathrm{a}}$ & $578^{\mathrm{b}}$ & $111^{\mathrm{C}}$ & $406^{d}$ & 39 & 1.6 & 1.9 & 1.7 & 0.7 & 0.95 \\
\hline n-6 series & & $222^{\mathrm{a}}$ & $543^{b}$ & $103^{\mathrm{c}}$ & $377^{d}$ & 36 & 1.3 & 1.3 & 1.4 & 0.5 & 0.41 \\
\hline $\mathrm{n}-3$ series & & $13^{\mathrm{a}}$ & $35^{\mathrm{b}}$ & $7^{a}$ & $28^{\mathrm{b}}$ & 4 & 0.3 & 0.6 & 0.3 & 0.2 & 0.25 \\
\hline Palmitic & $16: 0$ & $154^{\mathrm{a}}$ & $397^{\mathrm{b}}$ & $121^{\mathrm{C}}$ & $325^{d}$ & 14 & $29.6^{x}$ & $29.8^{x}$ & $27.8^{x}$ & $34.1^{y}$ & 1.71 \\
\hline Stearic & $18: 0$ & $224^{\mathrm{a}}$ & $449^{b}$ & $151^{\mathrm{C}}$ & $352^{\mathrm{d}}$ & 24 & 25.1 & 26.8 & 26.2 & 30.6 & 2.44 \\
\hline Oleic & $18: 1, \mathrm{n}-9$ & $109^{\mathrm{a}}$ & $326^{b}$ & $93^{a}$ & $248^{\mathrm{d}}$ & 16 & 4.2 & 5.8 & 5.7 & 3.9 & 1.17 \\
\hline Linoleic & $18: 2, n-6$ & $188^{\mathrm{a}}$ & $457^{b}$ & $81^{\mathrm{c}}$ & $318^{d}$ & 2 & 0.8 & 0.8 & 0.6 & 0.4 & 0.19 \\
\hline Arachidonic & $20: 4, n-6$ & $13^{\mathrm{a}}$ & $25^{\mathrm{b}}$ & $8^{\mathrm{a}}$ & $19^{a b}$ & 3 & $0.1^{x}$ & $0.2^{x y}$ & $0.4^{y}$ & $<0.1^{x}$ & 0.12 \\
\hline$\alpha$-Linolenic & $18: 3, n-3$ & $5^{\mathrm{a}}$ & $15^{\mathrm{b}}$ & $2^{a}$ & $11^{\mathrm{b}}$ & 2 & 0.1 & 0.4 & 0.1 & 0.1 & 0.19 \\
\hline Eicosopentaenoic & $20: 5, n-3$ & $6^{\mathrm{a}}$ & $15^{\mathrm{b}}$ & $5^{a}$ & $11^{\mathrm{b}}$ & 2 & 0.1 & 0.2 & 0.2 & $<0.1$ & 0.09 \\
\hline Docosahexaenoic & $22: 6, n-3$ & $1^{\mathrm{a}}$ & $3^{b}$ & $1^{\mathrm{a}}$ & $2^{\mathrm{ab}}$ & 0.5 & $<0.1$ & $<0.1$ & $<0.1$ & $<0.1$ & 0.02 \\
\hline
\end{tabular}

Means within rows with a different superscript are significantly $(P<0.05)$ different.

was lower. The percentage of monounsaturated fatty acids was greater in granulosa cells than in either plasma or COCs, and the percentage of PUFAs was less in follicular cells than in plasma.

\section{Discussion}

One of the major findings from this study was that the effects of altering dietary composition (both carbohydrate type and the level of fatty acids) on oocyte quality depend on the initial BCS of the animal. This is an important finding, for it confirms and possibly explains our previous observation, in a similar group of animals, that the effects of level of feeding on oocyte quality depend on animal body composition (Adamiak et al. 2005). In addition, in contrast to high-fibre diets, the effects of feeding high levels of starch or fatty acids in the present study were detrimental to post-fertilisation development in vitro, but only in low-BCS heifers. Similarly, the effects of diet composition on plasma hormone concentrations were observed only in the leaner group of animals. Furthermore, the effects of diet composition on oocyte quality occurred in the absence of any significant alteration to the fatty acid profile of COCs, although dietary lipid did increase the fatty acid content of COCs. Indeed, a second major finding from this study was the selective uptake of saturated fatty acids at the expense of mainly PUFAs within the follicular compartment.

\section{Endocrinology}

The substitution of starch for fibre in the diet increased plasma insulin in low-BCS heifers (from $\sim 11$ to $17 \mu \mathrm{lU} / \mathrm{ml}$ ), equivalent to the increase in plasma insulin (from $\sim 11$ to $22 \mu \mathrm{lU} / \mathrm{ml}$ ) observed for low-BCS heifers fed a comparable starch-based diet at maintenance $(M)$ and twice maintenance $(2 M)$ in the study of Adamiak et al. (2005). However, whereas the increase in plasma insulin concentrations with $2 \mathrm{M}$ feeding in that study was associated with increased blastocyst yields, the increase in plasma insulin associated with feeding starch-based diets in the present study was associated with reduced blastocyst yields (Table 3). Consequently, the detrimental effects of starch relative to fibre-based diets on oocyte quality may

Table 5 Fatty acid composition (\% w/w total fatty acids) of plasma, granulosa cells and cumulus-oocyte complexes.

\begin{tabular}{|c|c|c|c|c|c|}
\hline Fatty acids ( $\%$ of total) & Plasma & Granulosa cells & Cumulus-oocyte complexes & S.E.D. & Significance of effect \\
\hline Saturated & $51.6^{\mathrm{a}}$ & $55.7^{\mathrm{a}}$ & $86.3^{\mathrm{b}}$ & 1.92 & $P<0.001$ \\
\hline Unsaturated & $48.5^{\mathrm{a}}$ & $43.2^{\mathrm{a}}$ & $12.8^{\mathrm{b}}$ & 1.93 & $P<0.001$ \\
\hline Monounsaturated & $20.3^{a}$ & $32.6^{\mathrm{b}}$ & $11.6^{\mathrm{c}}$ & 1.15 & $P<0.001$ \\
\hline Polvunsaturated & $28.2^{\mathrm{a}}$ & $11.6^{\mathrm{b}}$ & $2.4^{\mathrm{C}}$ & 1.80 & $P<0.001$ \\
\hline $\mathrm{n}-6$ series & $26.4^{a}$ & $10.7^{\mathrm{b}}$ & $1.7^{\mathrm{c}}$ & 1.43 & $P<0.001$ \\
\hline$n-3$ series & $1.8^{\mathrm{a}}$ & $0.9^{\mathrm{b}}$ & $0.7^{\mathrm{b}}$ & 0.21 & $P<0.001$ \\
\hline Ratio n-6:n-3 & $16.6^{\mathrm{a}}$ & $10.9^{\mathrm{b}}$ & $4.1^{\mathrm{c}}$ & 1.80 & $P<0.001$ \\
\hline
\end{tabular}


be independent of the effects of insulin. Both increasing the level of feeding and substituting starch for fibre in the diet increase plasma insulin in low-BCS animals but, unlike the former, the latter dietary modification is associated with impaired embryo development.

Neither plasma IGF-I nor plasma leptin concentrations were significantly affected by dietary composition. However, plasma leptin concentrations were greater in moderate- than low-BCS heifers, an observation consistent with previous observations in this type of animal (Delavaud et al. 2002, Adamiak et al. 2005). Although it is difficult at present to reach a consensus on the effects of leptin on oocyte growth and maturation (Swain et al. 2004, Craig et al. 2005), it seems that, at lower physiological concentrations, leptin may have a positive effect on oocyte maturation and post-fertilisation development, so that elevated concentrations of this cytokine may have attenuated, in some way, the negative effects of feeding high levels of starch and fat on oocyte quality in moderate-BCS heifers in the present study.

The increase in plasma progesterone concentrations in low-BCS heifers offered Megalac (Table 2) is consistent with previous experiments with ruminants (Mattos et al. 2000), and may have arisen as a consequence of either the enhanced steroidogenic activity of the corpus lutea in heifers fed a palmitic acid-rich lipid source (Kuran et al. 1999), or a reduced rate of liver metabolism and clearance of progesterone from peripheral circulation (Hawkins et al. 1995).

\section{Principal carbohydrate source}

There has been only one previous attempt to assess the effects of altering the supply of dietary starch and digestible fibre on embryo quality in heifers (Yaakub et al. 1999, Wrenzycki et al. 2000). These authors reported a decrease in the number of 'transferable embryos' (based on morphological assessment) after ovarian stimulation and artificial insemination that was associated with an increase in the metabolism of $\left[2{ }^{14} \mathrm{C}\right]$ pyruvate in embryos derived from heifers offered the high-starch diet. This in turn was negatively correlated with transcript expression for the antioxidant enzyme $\mathrm{Cu} / \mathrm{Zn}$-SOD. These observations broadly agree with those presented in the current study, where the effects of dietary treatments were limited to the period of oocyte growth prior to the resumption of meiosis. The present study extends these observations and confirms our earlier findings (Adamiak et al. 2005) that the effects of diet depend on animal BCS, so that high-starch diets are detrimental to oocyte quality only in moderately thin animals. Unlike the study of Yaakub et al. (1999), dietary treatments in the current study were not extended beyond the period of fertilisation to include preimplantation development. However, using heifer serum from the current study to supplement SOF media during zygote culture in vitro, we also observed our starch-based diet to increase $\left[2-{ }^{14} \mathrm{C}\right]$ pyruvate metabolism in day-8 blastocysts, and this was associated with an increase in the proportion of TUNEL-positive cells (Adamiak et al. 2004). Consequently, one mechanism by which the feeding of highstarch diets may reduce post-fertilisation development, both in the current study and in that of Yaakub et al. (1999), may be through the production of free oxygen radicals within both the follicular compartment and the oviduct. Certainly, transcripts for a number of antioxidant enzymes are expressed to varying degrees in immature and meiotically mature oocytes (Lonergan et al. 2003). However, if this is the mechanism underlying the reduction in blastocyst yields when feeding high-starch diets to low-BCS heifers, it does not explain, in the current study, the increase in blastomere number (with no change in the percentage TUNEL-positive cells) in surviving embryos (Table 3), nor does it explain the apparent lack of an effect of high-starch diets on post-fertilisation development of oocytes from moderate-BCS heifers. At present, we are unable to advance a credible hypothesis to explain this effect of BCS, although it may involve leptin and differences in nutrient partitioning within animals that differ in body composition.

\section{Dietary lipid and fatty acids}

Proximate analysis of the experimental diets confirmed the greater lipid (acid hydrolysed ether extract (AHEE)) content of the Megalac-supplemented diets (Table 1). However, fatty acid composition of the diets was not determined in the current study; rather, the content and composition of fatty acids within plasma were used as a reference to assess the effects of diet composition on fatty acid uptake and metabolism within the follicular compartment.

Lipids are transported in plasma in the form of lipoproteins. For non-lactating cattle, approximately $90 \%$ of this lipoprotein fraction is in the form of high-density lipoprotein (HDL), which consists of approximately 54\% cholesterol esters, $25 \%$ cholesterol and 17\% phospholipids (Christie 1981). It is highly probably, therefore, that much of the fatty acids taken up by the follicular compartment in the present study was derived from $\mathrm{HDL}$, although this was not determined. Further, the paucity of biological material (i.e. the relative small numbers of COCs that could be recovered per animal) in the current study meant that no distinction could be made between polar and neutral fatty acids in these cells. Working with much greater numbers of oocytes, previous authors (e.g. McEvoy et al. 2000, Kim et al. 2001) reported the distribution (\% w/w) of lipid classes for bovine oocytes to be approximately $50 \%$ triglyceride, $29 \%$ phospholipid, $20 \%$ cholesterol and $10 \%$ free fatty acids. The proportion of saturated, monounsaturated and polyunsaturated fatty acids within each of these classes was remarkably consistent in the ruminant oocyte. It is not known whether these proportions can be altered in vivo by dietary composition, although it is worth noting that changing the composition of in vitro 
culture media (inclusion of serum rather than albumin) changed the relative amounts of fatty acids in neutral and polar lipids of bovine blastocysts (Reis et al. 2003).

An important finding of the present study was the apparent selective uptake of specific classes of fatty acids within the ovarian follicle that ensured the composition of the COC was low in unsaturated, particularly polyunsaturated, fatty acids (Table 5); similar observations have been made for sheep granulosa cells and oocytes by Reis et al. (2002). Importantly, unlike plasma, the profile of PUFAs in COCs in the present study was not affected to any significant degree by dietary composition. The fatty acid profile of COCs certainly bore little relation to that of plasma (Table 4), although this could be due in part to differences in the distribution of fatty acids within different fractions (i.e. cholesterol esters, phospholipids and triglycerides), as these are known to differ between tissues and plasma (Christie 1981).

Compared with other reports of the fatty acid composition of bovine mural-granulosa cells and oocytes (Kim et al. 2001, Zeron et al. 2001), the content of stearic acid (C18:0) was greater, whereas the contents of mono- and polyunsaturated fatty acids were somewhat less for COCs in the present study. This is almost certainly a reflection of the nature and composition of the experimental diets in the present study, although other factors such as genotype and season may have contributed (Zeron et al. 2001). Nevertheless, all reports agree that the most abundant fatty acids in ruminant oocytes are palmitic (C16:0), stearic (C18:0), oleic (C18:1) and linoleic (C18:2) acid.

Given the preferential uptake of saturated fatty acids by the $\mathrm{COC}$ within the follicular compartment and the fact that the composition of the lipid supplement used in this study comprised mostly these fatty acids, it is, perhaps, not surprising that the fatty acid profile of COCs was largely unaffected by dietary composition. Nevertheless, the inclusion of rumen bypass lipid in the diet of low-BCS heifers increased the total fatty acid content of COCs and reduced post-fertilisation development. Jorritsma et al. (2003) observed the concentration of non-esterified fatty acids (NEFA) in follicular fluid to increase when animals were placed in negative energy balance. The fatty acid profile of plasma NEFA is rich in saturated and monounsaturated fatty acids (21\% palmitic, $32 \%$ stearic and $37 \%$ oleic; Pethick \& Dunshea 1993). Although this profile differs slightly in follicular fluid $(23 \%, 13 \%$ and $33 \%$ for palmitic, stearic and oleic acids respectively), Leroy et al. (2004) found that the addition of both palmitic and stearic acids, at corresponding physiological concentrations, during in vitro maturation reduced subsequent cleavage and post-fertilisation development of bovine oocytes.

Finally, there was a significant reduction in the content of $n-6$ PUFAs within the COCs of moderate- compared with low-BCS heifers. It is noteworthy that the cleavage rate of oocytes from moderate-BCS heifers was also less than that for low-BCS heifers $(68 \%$ vs $76 \%$ respectively), and that this was associated with significantly lower concentrations of linoleic and arachidonic acid within the COC. These fatty acids are precursors for prostanoid synthesis (Abayasekara \& Wathes 1999) and, under the influence of cyclooxygenase-2 (COX-2), are metabolised to prostaglandin $E_{2}$ among other 2-series prostaglandins. COX-2 is expressed in bovine cumulus cells and, together with local prostanoid syntheses, is required for cumulus expansion and successful oocyte maturation (Calder et al. 2001, Nuttinck et al. 2002). At present, however, the functional significance of these observations remains to be confirmed, with no direct evidence of substrate-mediated alterations to these metabolic pathways affecting oocyte maturation and post-fertilisation development.

In conclusion, this study confirms and extends our previous findings that the effects of diet on oocyte quality depend on animal body composition. Diet-mediated alterations in plasma concentrations of key reproductive and metabolic hormones, in addition to oocyte quality, were detectable only in low-BCS animals. The underlying mechanisms for such effects remain elusive, although the inclusion of high levels of starch and fatty acids (mainly saturated fatty acids) in the diet of relatively lean oocyte donors reduces post-fertilisation development. For the range of diets offered in the present study, the follicular compartment was largely effective in ensuring oocytes of uniform fatty acid composition. The concentration of saturated fatty acids within COCs, however, is inherently high and it is possible that further increases in the content of these fatty acids, brought about by dietary lipid supplementation, impairs post-fertilisation development, perhaps by compromising membrane fluidity and function in ways that are not fully understood.

\section{Acknowledgements}

We thank Mr J C Rae and staff for animal supervision; Miss K Mackie, Mrs M Ewen and Messrs R Watt, A Thain and M Mitchell for technical assistance; and Dr Jim Craigon for statistical advice. This study was funded by the Department for Environment, Food and Rural Affairs. S A C receives financial assistance from the Scottish Executive for Environment and Rural Affairs Department. S J A was supported by the Perry Foundation and the University of Nottingham. The authors declare that there is no conflict of interest that would prejudice the impartiality of this scientific work.

\section{References}

Abayasekara DRE \& Wathes DC 1999 Effects of altering dietary fatty acid composition on prostaglandin synthesis and fertility. Prostaglandins, Leukotrienes, and Essential Fatty Acids 61 275-287.

Adamiak SJ, Ewen M, Powell KA, Rooke JA, Webb R \& Sinclair KD 2004 Inclusion of bovine serum from different dietary backgrounds influences embryo viability in vitro. Reproduction Abstract Series 3119.

Adamiak SJ, Mackie K, Watt RG, Webb R \& Sinclair KD 2005 Impact of nutrition on oocyte quality: cumulative effects of body composition and diet leading to hyperinsulinemia in cattle. Biology of Reproduction 73 918-926. 
AFRC (Agricultural and Food Research Council) 1993 Energy and Protein Requirements of Ruminants. An advisory manual prepared by the AFRC Technical Committee on Responses to Nutrients. Wallingford: $C A B$ International.

Armstrong DG, Duclos MJ \& Goddard C 1990 Biological activity of insulin-like growth factor-I purified from chicken serum. Domestic Animal Endocrinology 7 383-393.

Armstrong DG, McEvoy TG, Baxter G, Robinson JJ, Hogg CO, Woad KJ, Webb R \& Sinclair KD 2001 Effect of dietary energy and protein on bovine follicular dynamics and embryo production in vitro: associations with the ovarian insulin-like growth factor system. Biology of Reproduction 64 1624-1632.

Armstrong DG, Gong JG \& Webb R 2003 Interactions between nutrition and ovarian activity in cattle: physiological, cellular and molecular mechanisms. Reproduction Supplement 61 403-414.

Blache D, Tellam RL, Chagas LM, Blackberry MA, Vercoe PE \& Martin GB 2000 Level of nutrition affects leptin concentrations in plasma and cerebrospinal fluid in sheep. Journal of Endocrinology 165 625-637.

Blondin P, Bousquet D, Twagiramungu H, Barnes F \& Sirard MA 2002 Manipulation of follicular development to produce developmentally competent bovine oocytes. Biology of Reproduction $6638-43$

Calder MD, Caveney AN, Westhusin ME \& Watson AJ 2001 Cyclooxygenase-2 and prostaglandin $\mathrm{E}(2)(\mathrm{PGE}(2))$ receptor messenger RNAs are affected by bovine oocyte maturation time and cumulus-oocyte complex quality, and PGE(2) induces moderate expansion of the bovine cumulus in vitro. Biology of Reproduction 65 135-140.

Cameron JL 1996 Regulation of reproductive hormone secretion in primates by short-term changes in nutrition. Reviews of Reproduction $1117-126$.

Christie WW 1981 The composition, structure and function of lipids in the tissues of ruminant animals. In Lipid Metabolism in Ruminant Animals, pp 95-191. Ed. WW Christie. Oxford: Pergamon Press.

Christie WW 1982 Isolation of lipids from tissues. In Lipid Analysis: Isolation, Separation, Identification and Structural Analysis of Lipid, 2nd edn, pp 17-25. Oxford: Pergamon Press.

Christie WW, Noble RC \& Moore JH 1970 Determination of lipid classes by gas chromatography procedure. Analyst 95 940-944.

Craig JA, Zhu H, Dyce PW, Wen L \& Li J 2005 Leptin enhances porcine preimplantation embryo development in vitro. Molecular and Cellular Endocrinology 229 141-147.

Delavaud C, Ferlay A, Faulconnier Y, Bocquier F, Kann G \& Chilliard Y 2002 Plasma leptin concentration in adult cattle: effects of breed, adiposity, feeding level, and meal intake. Journal of Animal Science 80 1317-1328.

Demigne C, Yacoub C, Morand C \& Remesy C 1988 Findings on intermediate metabolism in ruminants. Reproduction, Nutrition, Development 28 1-17.

Genstat. 2002 Release 6 Reference Manual. Clarenden Press, Oxford: Oxford Science Publications.

Goodhand KL, Watt RG, Staines ME, Hutchinson JS \& Broadbent PJ 1999 In vivo oocyte recovery and in vitro embryo production from bovine donors aspirated at different frequencies or following FSH treatment. Theriogenology 51 951-961.

Greenwood FC, Hunter WM \& Glover JS 1963 The production of ${ }^{131}$ I-labelled human growth hormone of high specific radioactivity. Biochemistry Journal 89 114-123.

Hawkins DE, Niswender KD, Oss GM, Moeller CL, Odde KG, Sawyer HR \& Niswender GD 1995 An increase in serum lipids increases luteal lipid content and alters the disappearance rate of progesterone in cows. Journal of Animal Science 73 541-545.

Jorritsma R, de Groot MW, Vos PL, Kruip TA, Wensing T \& Noordhuizen JP 2003 Acute fasting in heifers as a model for assessing the relationship between plasma and follicular fluid NEFA concentrations. Theriogenology $60151-161$.

Kim JY, Kinoshita M, Ohnishi M \& Fukui Y 2001 Lipid and fatty acid analysis of fresh and frozen-thawed immature and in vitro matured bovine oocytes. Reproduction 122 131-138.
Kuran M, Onal AG, Robinson JJ, Mackie K, Speake BK \& McEvoy TG 1999 A dietary supplement of calcium soaps of fatty acids enhances luteal function in sheep. Animal Science 69 385-393.

Leroy JLMR, Vanholder T, Bols PEJ, De Clercq J \& Van Soom A 2004 The effect of negative energy balance associated nonesterified fatty acid levels during in vitro maturation of bovine oocytes on embryo production. In Proceedings of 20th Scientific Meeting of the AETE, Lyon, 10-11 September 2004, p 144 (Abstract).

Lonergan P, Gutierrez-Adan A, Rizos D, Pintado B, de la FJ \& Boland MP 2003 Relative messenger RNA abundance in bovine oocytes collected in vitro or in vivo before and $20 \mathrm{hr}$ after the preovulatory luteinizing hormone surge. Molecular Reproduction and Development 66 297-305.

Lowman BG, Scott NA \& Somerville SH 1976 Condition Scoring of Cattle (rev. edn). East of Scotland College of Agriculture, Bulletin no. 6.

Mattos R, Staples CR \& Thatcher WW 2000 Effects of dietary fatty acids on reproduction in ruminants. Reviews of Reproduction $\mathbf{5}$ $38-45$.

McEvoy TG, Coull GD, Broadbent PJ, Hutchinson JS \& Speake BK 2000 Fatty acid composition of lipids in immature cattle, pig and sheep oocytes with intact zona pellucida. Journal of Reproduction and Fertility 118 163-170.

McNeilly AS \& Fraser HM 1987 Effect of gonadotrophin-releasing hormone agonist-induced suppression of $\mathrm{LH}$ and $\mathrm{FSH}$ on follicle growth and corpus luteum function in the ewe. Journal of Endocrinology $115273-282$.

Nolan R, O'Callaghan D, Duby RT, Lonergan P \& Boland MP 1998 The influence of short-term nutrient changes on follicle growth and embryo production following superovulation in beef heifers. Theriogenology $501263-1274$

Nuttinck F, Reinaud P, Tricoire H, Vigneron C, Peynot N, Mialot JP, Mermillod P \& Charpigny G 2002 Cyclooxygenase-2 is expressed by cumulus cells during oocyte maturation in cattle. Molecular Reproduction and Development 61 93-101.

Owens PC, Johnson RJ, Campbell RG \& Ballard FJ 1990 Growth hormone increases insulin-like growth factor-I (IGF-I) and decreases IGF-II in plasma of growing pigs. Journal of Endocrinology 124 $269-275$.

Pethick DW \& Dunshea FR 1993 Fat metabolism and turnover. In Quantitative Aspects of Ruminant Digestion and Metabolism, pp 291-311. Eds JM Forbes \& J France. Wallingford: CAB International.

Reis A, Mitchell LM, Rooke JA, Ewen M, Lomax MA, Robinson JJ \& McEvoy TG 2002 Fatty acid profiles during development of sheep eggs in vivo. Theriogenology 57507 (Abstract).

Reis A, Rooke JA, McCallum GJ, Staines ME, Ewen M, Lomax MA \& McEvoy TG 2003 Fatty acid content of polar and neutral lipids from bovine blastocysts produced in vitro in the presence or absence of serum. Reproduction Abstract Series 30 57-58.

Schneider JE 2004 Energy balance and reproduction. Physiology and Behaviour 81 289-317.

Schneider JE, Blum RM \& Wade GN 2000 Metabolic control of food intake and estrous cycles in Syrian hamsters. I. Plasma insulin and leptin. American Journal of Physiology. Regulatory, Integrative and Comparative Physiology 278 R476-R485.

Sinclair KD, Kuran M, Gebbie FE, Webb R \& McEvoy TG 2000 Nitrogen metabolism and fertility in cattle. II. Development of oocytes recovered from heifers offered diets differing in their rate of nitrogen release in the rumen. Journal of Animal Science $\mathbf{7 8}$ $2670-2680$.

Sirard MA 2001 Resumption of meiosis: mechanism involved in meiotic progression and its relation with developmental competence. Theriogenology 55 1241-1254.

Starr JI, Horwitz DL, Rubenstein AH \& Mako ME 1979 Insulin, proinsulin and c-peptide. In Methods of Hormone Radioimmunoassay, 2nd edn. Eds BM Jaffer \& HR Behman. London: Academic Press. 
Swain JE, Dunn RL, McConnell D, Gonzalez-Martinez J \& Smith GD 2004 Direct effects of leptin on mouse reproductive function: regulation of follicular, oocyte, and embryo development. Biology of Reproduction 71 1446-1452.

Tervit HR, Whittingham DG \& Rowson LEA 1972 Successful culture in vitro of sheep and cattle ova. Journal of Reproduction and Fertility $30493-497$.

Vernon RG \& Peaker M 1983 The regulation of nutrient supply within the body. In Nutritional Physiology of Farm Animals, pp 114-174. Eds JAF Rook \& PC Thomas. Harlow: Longman.

Wrenzycki C, De Sousa P, Overstrom EW, Duby RT, Herrmann D, Watson AJ, Niemann H, O'Callaghan D \& Boland MP 2000 Effects of superovulated heifer diet type and quantity on relative mRNA abundances and pyruvate metabolism in recovered embryos. Journal of Reproduction and Fertility 118 69-78.

Yaakub H, O'Callaghan D \& Boland MP 1999 Effect of roughage type and concentrate supplementation on follicle numbers and in vitro fertilisation and development of oocytes recovered from beef heifers. Animal Reproduction Science 55 1-12.

Zeron Y, Ocheretny A, Kedar O, Borochov A, Sklan D \& Arav A 2001 Seasonal changes in bovine fertility: relation to developmental competence of oocytes, membrane properties and fatty acid composition of follicles. Reproduction 121 447-454.

Zeron Y, Sklan D \& Arav A 2002 Effect of polyunsaturated fatty acid supplementation on biophysical parameters and chilling sensitivity of ewe oocytes. Molecular Reproduction and Development 61 $271-278$.

Received 5 July 2005

First decision 5 September 2005

Revised manuscript received 6 October 2005

Accepted 11 October 2005 